\title{
Gazella bennetti (indian gazelle or chinkara) of Pakistan: genetic profiling and conservation priorities
}

\author{
Hussain, T.'; Manzoor F. ${ }^{2}$; Musthafa, M.M.; Marikar, F.M. ${ }^{4}$; Babar, M.E. ${ }^{1}$ \\ ${ }^{1}$ Dep. Molecular Biology, Univ. Pakistan (Lahore); ${ }^{2}$ Dep. Livestock Prod., Univ. Veterinary \\ (Lahore, Pakistan); ${ }^{3}$ Instit. Biol. Science, Univ. of Malaya (Kuala Lumpur), \\ ${ }^{4}$ Univ.Gen.S.J. Kotelawala Def. (Ratmalana, Sri Lanka). \\ E-mail: tanveer.hussain@vu.edu.pk
}

\begin{abstract}
Hussain, T.; Manzoor, F.; Musthafa, M.M.; Marikar, F.M.; Babar, M.E.: Gazella bennetti (indian gazelle or chinkara) of Pakistan: genetic profiles and conservation priorities. Rev. Vet. 31: 1, 14-19, 2020. Indian gazelle is endemic to wild northern Punjab, Pakistan, and also an endangered species according to red list categories of International Union of Conservation of Nature and Natural Resources. Better understanding of genetics of immune response of this species can be helpful to design effective conservation strategies. The objective of this study was to assess the molecular genetic diversity on interleukin 2 (IL-2) gene sequences of endangered $G$. bennetti as a gene encoding a cytokine involved in some vital activities of immune response regulation. The IL-2 gene (492 bp) was amplified and sequenced in DNA samples collected from wild as well as captive indian gazelle, followed by alignment and phylogenetic analysis. The neighbour joining tree constructed from MEGA6 showed that $G$. bennetti is differ from others and form in a different clade. The analysis of study results showed that indian gazelle is a unique isolated population found in Pakistan which is endemic as well as endangered. Therefore, in-situ and ex-situ conservation techniques for $G$. bennetti present a good solution to preserve this endangered species from extinction.
\end{abstract}

Key words: indian gazelle, Pakistan, phylogeny, endangered specie, wildlife.

\begin{abstract}
Resumen
Hussain, T.; Manzoor, F.; Musthafa, M.M.; Marikar, F.M.; Babar, M.E.: Gazella bennetti (gacela india o chinkara) de Pakistán: perfiles genéticos y prioridades de conservación. Rev. Vet. 31: 1, 14-19, 2020. La gacela india es oriunda de la zona silvestre del norte de Pendjab (Pakistán). De acuerdo a las categorías de la lista roja de la Unión Internacional de Conservación de la Naturaleza y los Recursos Naturales, constituye una especie en peligro. El entendimiento de la genética de la respuesta inmune en esta especie puede ser útil para diseñar efectivas estrategias de conservación. El objetivo del estudio fue evaluar la diversidad genética molecular en la interleukina 2 (IL-2), secuencias de genes que ponen en peligro a $G$. bennetti como un gen que codifica una citokina involucrada en algunas actividades vitales de regulación de la respuesta inmune. El gen IL-2 (492 bp) fue amplificado y secuenciado en muestras de ADN colectadas de la naturaleza, así como de ejemplares cautivos de gacela india, seguidos por la alineación y el análisis filogenético. Los vecinos que unen el árbol construido de MEGA6 mostraron que $G$. bennetti es distinto de otros y forma un clado diferente. El análisis de los resultados del estudio mostró que las gacelas indias constituyen una única población aislada encontrada en Pakistán, la cual es endémica y está expuesta al peligro. Por consiguiente, las técnicas de conservación in-situ y ex-situ para G. bennetti constituyen una buena alternativa para evitar el peligro de extinción de la especie.
\end{abstract}

Palabras clave: gacela india, Pakistán, filogenia, especie en peligro, vida salvaje.

\section{INTRODUCTION}

The genus Gazella (family: Bovidae, subfamily: Antilopinae) is represented by 14 species of ungulates ${ }^{12}$ with a wide distribution across Asia, Africa, and the Middle East ${ }^{14,21}$. However, Gazella bennetti (indian

Recibido: noviembre 2019 / Aceptado: febrero 2020 gazelle or chinkara) is primarily habituates in the indian subcontinent ${ }^{19,24,25}$, with the biggest share is reported in the Rajasthan state of India and in Khyber Pakhtunkhwa Province of Pakistan 7, 13, 26, 27 .

Their distribution is now facing drastic population decline ${ }^{1,6,7,17,18,22,25,27}$ due to over hunting, habitat depletion, poaching, road widening projects, vehicular movement and lack of conservation awareness 9, 14, 17,27 . 
Hunting has been regarded as the major threat for gazelle populations, combined with the recent anthropogenic and climatic changes (rapid human population growth, unprecedented infrastructure developments, intensive agriculture). These have resulted in the fragmentation of gazelle populations throughout their ranges which has raised some concerns about their conservation status and future survival very lately ${ }^{14}$.

During 1950s G. bennetti was considered threatened but in 1994 it was categorized as vulnerable and later it was considered of lower risk in 1996. Under the Wildlife (Protection) Act of India this species listed as a Schedule 1 species in 1972. According to IUCN Red Data list (2002), this species has been categorized under "Lower Risk/Conservation Dependent (LR/CD)".

Under the Indian law, chinkara is fully protected, occupying $80 \%$ of India as protected land, $9 \%$ of Iran and $5 \%$ of Pakistan. According to authors ${ }^{27}$ this species has been exterminated in the Pakistan sector of the Thar Desert chiefly by habitat loss. Based on Punjab Wildlife Act, G. bennetti is a protected animal in Punjab province but their population status is not well known ${ }^{1}$.

Effective immune system counteracting pathogenic viruses, microorganisms and parasites is a fundamental requirement for the survival of an organism ${ }^{32}$. Interleukins are a group of cytokines (secreted proteins/ signalling molecules) expressed by leukocytes, where they are recognised as regulators of inflammatory and immune responses ${ }^{29}$. Interleukin-2 (IL-2) plays a very important role in T-helper cell defense, especially in immune response to infectious diseases. T-cell growth factor, known as interleukin 2, is a lymphokine produced by mitogen activated T-cells 4,10 .

At present, limited published information is available in the relevant scientific literature based on this important gene diversity and polymorphism in animals ${ }^{32}$. In cattle, radioactive in situ hybridisation analyses showed that IL-2 gene was localised to the $\mathrm{q} 22 \rightarrow \mathrm{q} 23$ bands of chromosome 17. Gene location homology and increasing evidence for chromosomal band formation within the Bovidae suggests that the IL-2 gene maps to chromosome 17 in goats, buffaloes and sheep ${ }^{5}$.

Since the IL-2 gene evolves at a rapid pace in ruminants, study of this gene could give more insight on adaptive selection over short evolutionary period ${ }^{33}$. Therefore, this investigation was aimed to determine the origin and genetic diversity of Gazella bennetti (Indian gazelle or chinkara) of Pakistan based on IL-2 gene.

Small, scattered population within a narrow range of habitats usually faces pressure for their survival ${ }^{3}$. Vulnerability of small pockets of populations to extinction from stochastic events increases many fold when their genetic diversity combined with inbreeding depression shows lower values ${ }^{20}$.

It has been reported that number of subspecies of G. bennettii ${ }^{25}$ such as G.b. bennettii, G.b. chiristii, G.b. fusciforms, G.b. karamii, G.b. salinarum and
G.b. shikariiand taxonomic classification of G. bennettii varies very widely. Therefore, genetic profiling and conservation of this protected animal is very important in preserving local animal genetic diversity of Pakistan.

\section{MATERIAL AND METHODS}

Samples collection. Twenty unrelated $(\mathrm{n}=20)$ individuals of Gazella bennetti (Indian gazelle or chinkara) of Pakistan, with typical phenotypic features, were collected from the wild as well as from captive locations after rather extensive field search in their natural habitats. Three $\mathrm{mL}$ blood was collected aseptically from each animal from the jugular vein of Gazella bennetti confiscated by the Punjab Wildlife and Parks Department and brought to Loi Bher Wildlife Park, Rawalpindi, and Lahore Zoo with $0.5 \mathrm{M}$ ethylene-diaminetetra-acetic acid (EDTA) as an anti-coagulant. The blood samples were stored on ice immediately after collection. They were then brought to the laboratory and further stored temporarily at $-20^{\circ} \mathrm{C}$ prior to DNA extraction. Hair and skin samples of Gazella bennetti were collected from wild animals in Salt Range, Kala Chitta mountain range region of Punjab.

DNA extraction and quantification. The stored samples were thawed (at roomtemperature using water bath) for the genomic DNA isolation using DNA extraction kit (BioBasic, Canada) as per manufacturer's guidelines and stored at $-20^{\circ} \mathrm{C}$ for further use. Quantification of the extracted DNA samples was carried out with the help of agarose gel electrophoresis $(0.8 \%)$ as well as Nano Drop (Thermoscientific, USA). Standard DNA/DNA ladder was added. All samples were brought to same level of concentration of $50 \mathrm{ng} / \mu \mathrm{L}$.

Primers and PCR amplification. Amplification of IL-2 specific primers -IL-2 Forward 5'CCCATCATATTTTTCCAGA3' and IL-2 Reverse 5'TGCTATTAATCC AGTTAGTG TG3' (Ovine chromosome 17 ranging from 37994357 to 37994848 ) were designed from Ovisaries IL-2 precursor gene (AF287479) available at Gen Bank, National Centre for Biotechnology Information (NCBI) using Primer 3 software and In Silico PCR web facility ${ }^{28}$. PCR was performed according to the protocol of primers set, DNA polymerase, polymerase chain reaction (PCR) buffer, dNTPs, $\mathrm{MgCl} 2$, genomic DNA and nuclease-free water were used for the targeted (492 bp) regions amplification using thermocycler (Icycler Bio Rad, USA). PCR was performed in reaction volume of $25 \mu \mathrm{L}$ using cycling conditions: initial denaturation at $95^{\circ} \mathrm{C}$ for $4 \mathrm{~min}$ followed by 35 cycles of $94^{\circ} \mathrm{C}$ for $1 \mathrm{~min} ; 54^{\circ} \mathrm{C}$ for $1 \mathrm{~min}$; $72^{\circ} \mathrm{C}$ for $1 \mathrm{~min}$ with final extension at $72^{\circ} \mathrm{C}$ for $7 \mathrm{~min}$.

Sequencing. PCR amplifications were seen by running $6 \mu \mathrm{L}$ of PCR product mixed with $2 \mu \mathrm{L}$ of loading dye on $1.5 \%$ agarose gel at a constant voltage of $100 \mathrm{~V}$ for $50 \mathrm{~min}$ in $1 \times \mathrm{TAE}$ buffer. The resulting bands were 


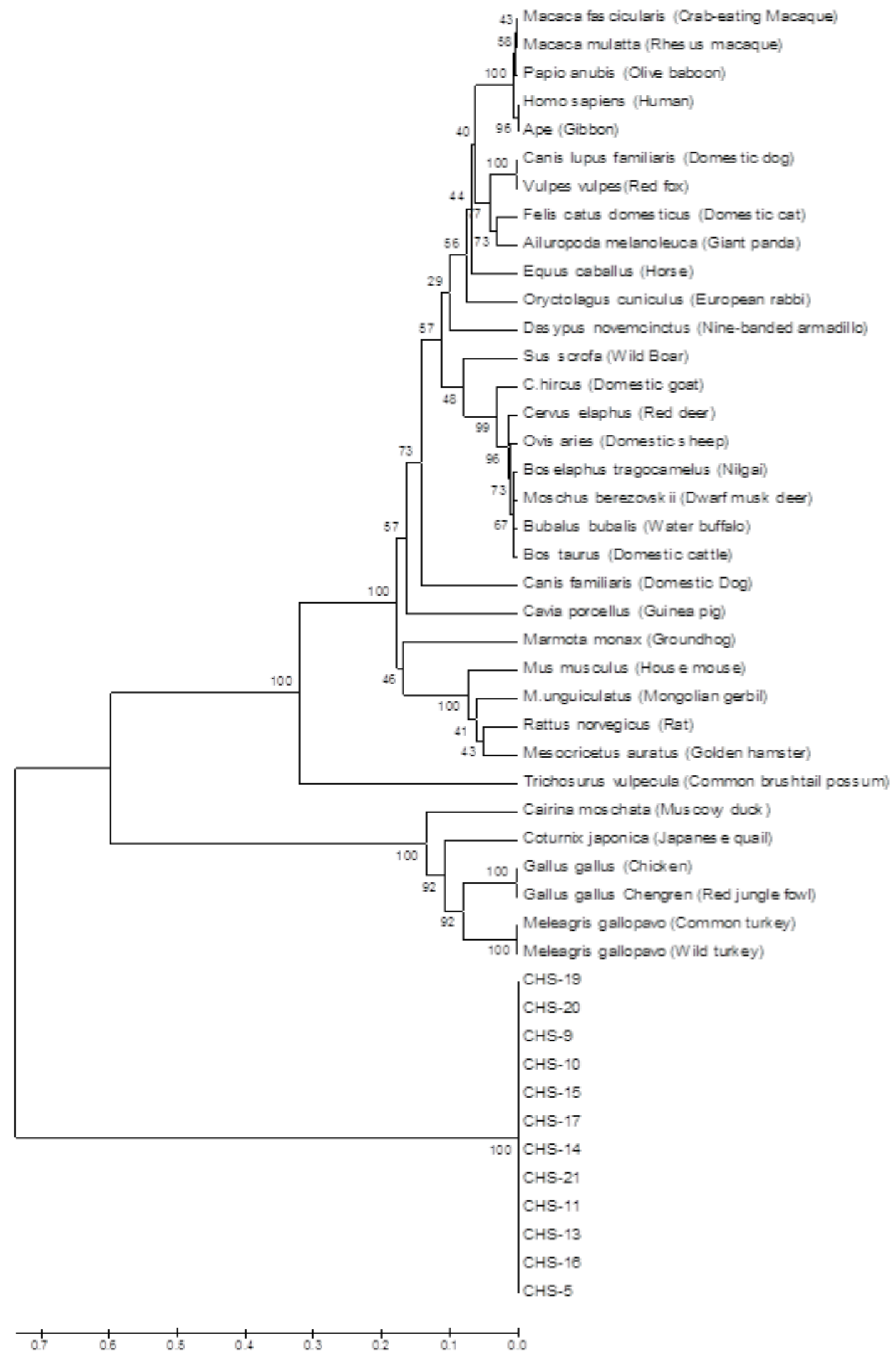

Figure 1. Neighbour joining tree constructed with MEGA6 using IL-2 sequences from indian gazelle (chinkara) and other different mammalian species. 
visualised under UV light using gel documentation system (BioRad, USA). The amplified PCR products were purified using DP203-TIANquick Mini Purification Kit (China) as per provided instructions. The quality of DNA was examined on $2 \%$ agarose gel. Purified PCR products were then sent to Singapore for Sanger's sequencing.

Bioinformatics analysis. The sequences were aligned by using NCBI BLAST tool and Codon Code Aligner software was used for sequence editing, alignment and detection of variable sites. Finally, trimmed and edited sequences of $433 \mathrm{bp}$ were used for further analyses. DnaSP was used to measure the nucleotide and haplo type diversity, while MEGA 6 programme was used for phylogenetic analysis using neighbor joining method with 1000 bootstrap value and amino acid analysis ${ }^{30}$. The sequence analysis was compared with the available amino acid sequences of other Gazella bennetti species, with respect to Macaca fascicularis (crab-eating macaque); Macaca mulatta (rhesus macaque); Papio anubis (olive baboon); Homo sapiens (human); Ape (gibbon); Canis lupus familiaris (domestic dog); Vulpes vulpes (red fox); Felis catus domesticus (domestic cat); Ailuropoda melanoleuca (giant panda); Equus caballus (horse); Oryctolagus cuniculus (european rabbit); Dasypus novemcinctus (nine-banded armadillo); Sus scofa (wild boar); Capra hircus (domestic goat); Cervus elaphus (red deer); Ovis aries (domestic sheep); Boselaphus tragocamelus (nilgai); Moschus berezovskii (dwarf musk deer); Bubalus bubalis (water buffalo); Bos taurus (domestic cattle); Canis familiaris (domestic dog); Cavia porcellus (guinea pig); Marmota monax (groundhog); Mus musculus (house mouse); Mus unguiculatus (mongolian gerbil); Rattus norvegicus (rat); Mesocricetus auratus (golden hamster); Trichosurus vulpecula (common brushtail possum); Cairina moschata (muscovy duck); Coturnix japonica (japanese quail); Gallus gallus (chicken); Gallus gallus chengren (red jungle fowl); Meleagris gallopavo (common turkey); and Meleagris gallopavo (wild turkey).

\section{RESULTS}

To make phylogenetic sense of the diversity of IL-2 haplotypes attributed to, we aligned representative sequences of the IL2 of twelve individuals of Gazella bennetti. The amplification of all the samples at DNA encoding region of Indian gazelle or chinkara IL-2, 492 bp target region was successful sequenced.

It had confirmed the localisation of IL-2 gene at the q $22 \rightarrow$ q23 bands of chromosome 17 in Indian gazelle (chinkara) as previously suggested by authors $5,8,15$. The neighbour joining tree showed that Gazella Bennetti is in a different clade which highlights its importance (Figure 1).

Phylogenetic analysis revealed that the IL-2 sequences of different tested ruminants here are form a different cluster. Gazella bennetti IL-2 is in a different clade shows its evolutionarily more important than any other animals. Gazella bennetti IL-2 is evolutionarily more superior with other animals, and it might have diverged recently from the same ancestor.

\section{DISCUSSION}

Due to highly fragmented world, where wildlife fauna and flora have rather limited opportunity to maintain gene-flow and thereby overall effective population size, it becomes imperative for management policies to encourage genetic diversity.

The ultimate goal should be the maintenance of maximum diversity within wildlife pristine populations to ensure maximum potential to respond to environmental perturbations; population management decisions need to be based on maintaining genetic diversity rather than maintaining unique populations, such as subspecies ${ }^{20}$.

As an endangered species, the Indian gazelle, is going through several pressures for its survival and it is high time to consider conservation of this animal from extinction. Even though the gazelle closely resembles some of its ancestral forms of domestic sheep, it has a genetically distinct population.

For many domestic animal populations, uniqueness is broadly defined and differences between populations may be the functions of few different genes, often closely related with a lone physical character or small group of specific characters ${ }^{11,16}$

Any population(s) that had been isolated historically, biogeographically or reproductively, might be considered to be a unique population ${ }^{16}$ such as the Indian gazelle, where it represents an important source of uncharacterised genetic diversity, and adaptations restricted to less intensively managed highland populations. Perseverance of feral populations that are highly valuable but vulnerable sources of genetic diversity for domestic relatives has been highlighted in other species ${ }^{23,31}$

Since the reported population estimate of Indian gazelle is merely around 1,000 this number is much lower than the suggested number of individuals required for protecting adaptive genetic variation in a breeding population. Therefore, in situ and ex situ conservation techniques for this animal will be a good solution to preserve this endangered animal species from extinction.

Furthermore, as suggested by authors ${ }^{2}$, the community participation bordering the wildlife sanctuaries and game reserves could improve the conservation of Indian gazelle. Since this vital biodiversity component of Pakistan face threats from different fronts, the recovery system should also include all possible mechanisms to protect them.

Also, according to several analyses presented in this study, the Indian gazelle has a unique isolated population in Pakistan that is endemic and endangered as well. Despite the negligence of good management 
practices for conservation of the gazelle, it maintains a distinct genetic signature that should be conserved immediately by the relevant stakeholders.

In light of the above-mentioned rather limited number and highly restricted geographical distribution of the Indian gazelle, this animal should be classified as rare in terms of its population with extinction status for the provision of appropriate conservation measures. This study illustrates the genetic diversity and taxonomic relevance (with related animals) in feral and poorly managed populations to unravel genetic structure and relatedness.

In conclusion, with regard to the studied gene encoding IL-2 production, the study provides new information and knowledge in support of conservation strategies of endangered breeds. Further studies on gazelle on these lines should enhance our understanding of their genetic diversity patterns, genetic finger-printing and bottleneck tests. Our results are relevant to phylogenic position of Indian gazelle and its taxonomic distinctiveness from other gazelle species distinction would require separate conservation measures.

Acknowledgements. The WWF-Pakistan is acknowledged for funding the project SGP-50047701; the DNA samples used were collected under this project.

\section{REFERENCES}

1. Arshad M, Hussain A. 2010. Population status of indian chinkara in Cholistan Game Reserve, Punjab, Pakistan. Russian J Ecol 41: 524-530.

2. Awan AG. 2006. Conservation of Punjab urial (Ovis vignei punjabiensis) through long-term monitoring of marked individuals. The Rufford Maurice Laing Foundation, London, UK, p. 1-22.

3. Ayaz S et al. 2012. Behaviour and biology of Ovis orientalis (URIAL) in Kotal Wild Life Park and Borraka Wild Life Sanctuary. J Anim \& Plant Sci 22: 29-31.

4. Bressani F et al. 2014. Single nucleotide polymorphisms in candidate genes associated with gastrointestinal nematode infection in goats. Genet \& Molec Res 13: 8530-8536.

5. Chowdhary BP, Hassanane MS, Gustovsson I. 1994. Regional localization of the bovine interleukin-2 (IL2) gene to chromosome 17q22--> 23 by in situ hybridization. Cytogenet \& Cell Genet 65: 166-168.

6. Dookia S. 2007. Participation of local villagers in conservation of indian gazelle or chinkara (Gazella bennettii) in Thar desert of Rajasthan, India. The Rufford Maurice Laing Foundation, London. https://www.revolvy.com/page/ Rufford-Foundation

7. Dookia S, Rawat M, Jakher GR, Dookia BR. 2009. Status of indian gazelle (Gazella bennettii Sykes, 1831) in the Thar Seaert of Rajasthan, India. In: Faunal Ecology and Conservation of the Great Indian Desert (Sivaperuman C, Baqri QM, Ramaswamy G, Naseema M, editors), Springer, Berlin.

8. Echard G, Broad TE, Hill D, Pearce P. 1994. Present status of the ovine gene map (Ovisaries); comparison with the bovine map (Bos taurus). Mammalian Genome 5: 324332 .

9. Gaikwad MC, Narwade SS. 2016. The status of chinkara Gazella bennettii (Mammalia: Cetartiodactyla: Bovidae) at Mayureshwar Wildlife Sanctuary. India J Threat Taxa 8; 8590-8595.

10. Gillis S, Firm MM, Ou W, Smith KA. 1978. T cell growth factor: Parameters of production and a quantitative microassay for activity. J Immunol 120: 2027-2032.

11. Groeneveld LF et al. 2010. Genetic diversity in farm animals: A review. Anim Genet 41: 1-26.

12. Groves CP. 1985. An introduction to the gazelles. Chinkara 1: 4-16.

13. Habibi K. 2001. Pakistan. In: Antelopes. Part 4: North Africa, the Middle East, and Asia (Mallon DP, Kingswood SC eds), IUCN, Gland, Switzerland, p. 122-128.

14. Hadas L et al. 2015. Wild gazelles of the southern levant: genetic profiling defines new conservation priorities. Plos One 10(3): e0116401. https://doi.org/10.1371

15. Hediger R, Ansari HA, Stranzinger GF. 1991. Chromosome banding and gene localizations support extensive conservation of chromosome structure between cattle and sheep. Cytogenet \& Cell Genet 57: 127-134.

16. Henson EL. 1992. In situ conservation of livestock and poultry, FAO Animal Pro- duction and Health Paper, FAO, $\mathrm{N}^{\circ}$ 99, Rome, p. 254-358.

17. IUCN SSC Antelope Specialist Group. 2017. Gazella bennettii. The IUCN red list of threatened species. http:// dx.doi.org/10.2305/IUCN.UK.2017-2.RLTS.T8978A.

18. Jakher G, Dookia S, Dookia B. 2002. Herd composition and population dynamics of Gazella bennetti (Sykes,1831) in Gogelao Enclosure (Nagaur), Rajastan. Zoos' Print Journal 17: 936-938.

19. Kankane PL. 2000. Status survey of chinkara and desert cat in Rajasthan. Rec Zool Surv India (Kolkata Occ.), 179: 71.

20. Larson S. 2012. Loss of genetic diversity in wild populations. In: Analysis of genetic variation in animals (M. Caliskan ed.), Tech Publishers, Croatia, p. 231-242.

21. Lerp H, Wronski T, Butynski TM, Plath M. 2013. Speciation of arabian gazelles. In: Speciation: natural processes (P.Michalak ed.), Nova Science, New York, p. 5982.

22. Mallon DP. 2008. Gazella bennettii. The IUCN red list of threatened species. http://dx.doi.org/10.2305/IUCN. UK.2008.RLTS.T8978A12945880

23. Medugorac I et al. 2009. Genetic diversity of european cattle breeds highlights the conservation value of traditional unselected breeds with high effective population size. Molec Ecol 18: 3394-3410.

24. Prakash I. 1991. Ecology of artiodactyles in the Thar desert: their conservation in the desert biosphere reserve. In: Mammals in the palaearctic desert (McNeely JA, Neronov VM eds), Russian Acad Sci Moscow, p. 243-250.

25. Rahmani A. 1990. Distribution, density, group size and conservation of indian gazelle, Gazella bennettii (Sykes 1831) in Rajistan, India. Biol Conserv 51: 171-189.

26. Rahmani AR. 2001. India. In: Antelopes. Part 4: North Africa, the middle east, and Asia. Global survey and re- 
gional action plans (Mallon DP \& Kingswood SC eds.), IUCN, Gland, Switzerland, p. 178-187.

27. Roberts TJ. 1977. The mammals of Pakistan, ed. Ernest Benn, London, $361 \mathrm{p}$.

28. Rozan S, Skaletsky JH. 2000. Primer3 on the WWW for general users and for biologist programmers. In: Bioinformatics methods and protocols: methods in molecular biology (Krawetz S \& Misener S ed.), Humana Press Totowa, NJ, USA, p. 365-386.

29. Sotiriou I, Makris D. 2013. Genetic implications in COPD. The current knowledge. Open Journal of Respiratory Diseases 3: 52-62.

30. Tamura KD et al. 2011. MEGA6: molecular evolutionary genetics analysis using maximum likelihood, evolutionary distance, and maximum parsimony methods. Molec Biol \& Evolut 28: 2731-2739.

31. Tapio M et al. 2005. Native breeds demonstrate high contributions to the molecular variation in northern European sheep. Molec Ecol 14: 3951-3963.

32. Turner AK et al. 2011. Genetic diversity in cytokines associated with immune variation and resistance to multiple pathogens in a natural rodent population. PLoS Genetics: 7, e1002343.

33. Zelus D, Rechavi RM, Delacre M, Auriault C, Laudet V. 2000. Fast evolution of interleukin-2 in mammals and positive selection in ruminants. J Molec Evol 51: 234-244. 